Int. J. Dev. Biol. 50: 3-15 (2006)

doi: $10.1387 / \mathrm{ijdb} .052095 \mathrm{cs}$

Special Contribution

\title{
Head-tail patterning of the vertebrate embryo: one, two or many unresolved problems?
}

\author{
CLAUDIO D. STERN ${ }^{1, *}$, JEROEN CHARITÉ2 ${ }^{2}$ JACOUELINE DESCHAMPS ${ }^{3}$, DENIS DUBOULE ${ }^{4}$, \\ ANTHONY J. DURSTON ${ }^{3}, \#$, MARIE KMITA ${ }^{4}$, JEAN-FRANÇOIS NICOLAS ${ }^{5}$, ISABEL PALMEIRIM ${ }^{6}$, JIM C. SMITH $^{7}$ \\ and LEWIS WOLPERT ${ }^{1}$ \\ European Union Network of Excellence "Cells into Organs". ${ }^{1}$ Department of Anatomy \& Developmental Biology, University College \\ London, U.K., ${ }^{2}$ Department of Cell Biology and Genetics, Erasmus University Rotterdam, The Netherlands, ${ }^{3} \mathrm{Hubrecht}$ Laboratory / NIOB, \\ Utrecht, The Netherlands, ${ }^{4}$ Département de Biologie Animale, Université de Genève, Switzerland, ${ }^{5}$ Unité de Biologie Moléculaire du \\ Développement, Institut Pasteur, Paris, France, ${ }^{6}$ Escola de Ciências da Saúde/Instituto de Investigação em Ciências da Vida e Saúde, \\ Universidade do Minho, Braga, Portugal and ${ }^{7}$ Wellcome/CR-UK Gurdon Institute for Cancer and Developmental Biology, Cambridge, U.K.
}

\section{Introduction}

One of the most important reasons why the problem of headtail patterning has eluded a solution is that it is not even easy to define this axis precisely in the vertebrate embryo. Although the orientation of the embryo is fixed relatively early in development, the cells that will occupy different positions along the axis are not identifiable until relatively late stages, at least in amniote (birds and mammals) embryos. To understand the problem we need to begin with the fly Drosophila, whose head-tail axis is well defined from an early stage and in which species many of the key players have been identified.

\section{Two different modes of head-tail patterning in inverte- brates}

Polarity establishment requires a symmetry-breaking event, resulting in an axis along which determinants are segregated. In the nematode Caenorhabditis elegans, oocytes are apolar and are triggered to polarize rapidly along one axis after fertilization (Cowan and Hyman, 2004). In Drosophila (reviewed in Akam, 1987; Lall and Patel, 2001; Huynh and St Johnston, 2004; Tautz, 2004), maternal gene products become distributed in a graded fashion along the long axis of the cytoplasm of the oval-shaped fertilized egg. The antero-posteror axis is specified maternally and is related to the axis of the mother, the key maternal determinants being localised during oogenesis. In particular, bicoid mRNA becomes concentrated in the future anterior (see Boxes 1 and 2) pole of the egg, thereby creating a gradient of Bicoid protein along the head-tail axis; bicoid mutant flies are "doublecaudal" (double-posterior). When cellularization occurs to form the blastoderm, different cells inherit different amounts of Bicoid (and other proteins), causing a preliminary specification of their fates, such that cells inheriting the highest doses of Bicoid become rostral (anterior) in nature. Bicoid specifies the activity of the gap genes at different positions along the axis; subsequent interactions between cells, involving Pair-rule and Segmentation genes, gradually cause the subdivision of the blastoderm into progressively smaller regions along this axis, setting up the rough head-tail body plan of the larva, which is subdivided into 14 segments. The dorso-ventral axis is specified by maternal Dorsal gene activity, (a NF-îB homolog) which is expressed at high levels ventrally and decreasing dorsally, where $d p p$ (a BMP homolog) is expressed. Thus, the axes of the fly are initially specified by unequal distribution of maternal determinants within the egg cytoplasm.

Drosophila, like other flies, is a holometabolous, long-germband insect and the initial body pattern of the larva is essentially restructured, to be rebuilt again later from imaginal discs that are set aside in the larva. Short-germ-band insects and other arthropods establish their head-tail axis rather differently: they lay down their body segments in a slow, progressive way, from head to tail. At early stages of development, not all the cells that will contribute to different parts of the axis are yet present - cells destined for the most caudal parts are generated much later than

Abbreviations used in this paper: AP, anteroposterior; IM, involuted mesoderm; NE, neurectoderm; NOM, non-organizer mesoderm.

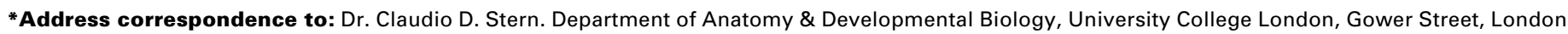
WC1E 6BT, U.K. Fax: +44-20-7679-2091. e-mail: c.stern@ucl.ac.uk

\#Present address: Instituut Biologie Leiden, Wiskunde en Natuurwetenschappen, Universiteit Leiden, The Netherlands.

0214-6282/2006/\$25.00

(c) UBC Press

Printed in Spain

www.intjdevbiol.com 
the overall orientation of the embryo. An extreme case is the centipede, which according to the species develops anything between 15 and 151 segments (but always an odd number) (Chipman et al., 2004). At least in the leech there is a set of dividing progenitors set aside whose progeny progressively contributes to more caudal regions: the most recently a cell is born, the more caudally it will be located in the final plan (Lall and Patel, 2001; Tautz, 2004). It is clear that in such systems, where the body plan is laid down progressively from head to tail over a long period, segment identity must be established during this process rather than all at once for the entire organism, as it is in Drosophila.

\section{The head-tail axis in vertebrates: where is it?}

Textbooks and even some primary papers make the assumption that, as in the fly, vertebrate embryos specify their head-tail axis very early in development, even before gastrulation. Thus, diagrams depicting the organization of the early (blastula- or early gastrula-stage) embryo may include indications of rostral (such as forebrain; Fig. 1) and caudal. However, it is important to distinguish between cell fates and embryonic locations. While the future positions of the head and tail are specified very early in development in most animals, it is generally impossible to find cells that will contribute progeny restricted to a single region of the axis, certainly for regions caudal to the hindbrain. At least in amniotes, although much of the head region is laid down and may be specified relatively early in development, the rest of the body, from the hindbrain to the tail, is laid down progressively and slowly, at stages of development much later than gastrulation (as in short germ band insects). It is therefore not possible to identify cells destined to contribute to particular regions of the trunk until relatively late stages. Although the embryo as a whole is indeed patterned and the positions at which the head, trunk and tail will develop can be defined at the blastula stage, the cells themselves have not yet been born and therefore cannot be identified or marked at this stage (Fraser and Stern, 2004). As a consequence when we talk about "patterning of the head-tail axis" we mean different things depending on whether we

Box 1. Naming the axes. In Drosophila and most other animals, the long axis of the body is usually called the "anterior-posterior" axis, meaning front-back. However in humans, which walk erect, "anterior" means ventral (belly) and "posterior" is dorsal (the back, or spine), which causes confusion. To avoid ambiguity we use "headtail" or "rostro-caudal" for this axis, and "dorso-ventral" for the bellyto-back axis in all organisms.

look at positions in the embryo or whether we are referring to cells with specific positional identity. It is crucial to bear this distinction in mind when trying to understand the mechanisms responsible for these patterning events.

There may also be some very significant differences between different vertebrate Classes, perhaps according to how fast they develop and whether the volume of the embryo as a whole increases significantly during development or whether, as in the fly, embryo volume remains more or less constant during the
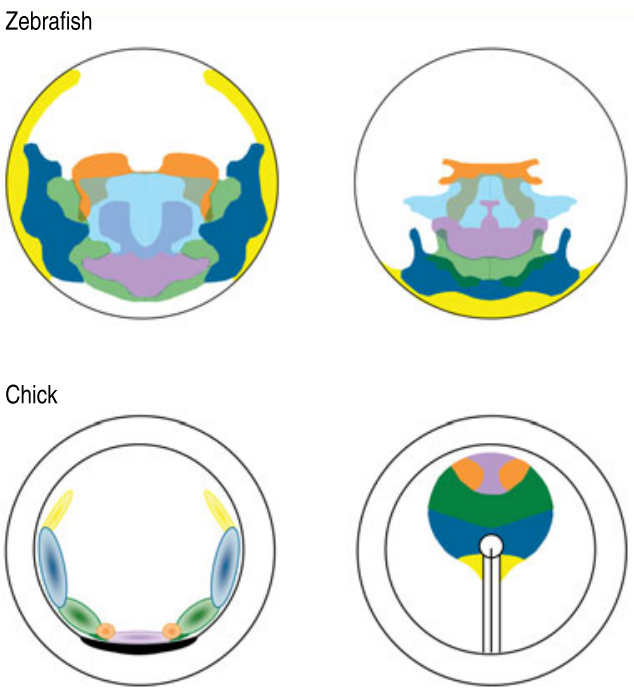

Telencephalon

Midbrain

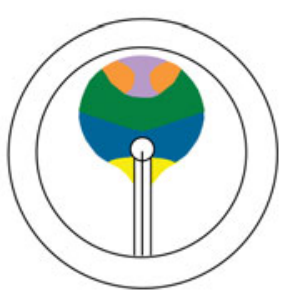

Diencephalon
Hindbrain
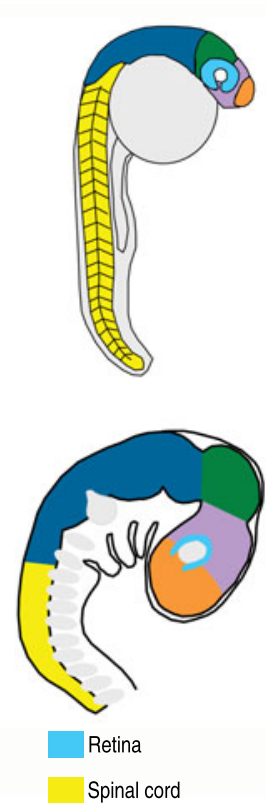

Fig. 1. Rough fate maps of zebrafish (upper row) and chick (lower row) embryos at early blastula (left), gastrula (middle) and a stage when the nervous system has been roughly patterned (right). The earliest stage chick embryo displays predictions of the locations of the centres of these prospective territories since the regions overlap considerably at this stage. Based on data from Woo and Fraser 1995), Hatada and Stern (1994) and various fate maps from the literature.

early, patterning stages. Anurans like the frog Xenopus laevis develop very fast to a free-swimming tadpole stage and do not increase in volume at all between fertilization and hatching of the tadpole: instead, cells become progressively smaller as they divide. In Xenopus there has been some controversy about how the head-tail axis should be fate-mapped to the early (blastula- or early gastrula-stage) embryo. Because treatments (such as Lithium Chloride) that cause dorsalization of the embryo also generate a bigger head and trunk/tail truncations, while ventralizing treatments (such as BMP, or ultra-violet irradiation) cause head deletions and an exaggerated trunk/tail, some papers assumed that the dorso-ventral and the head-tail axes are coincident in the blastula. But this cannot be true (see Stern et al., 1992; Lane and Sheets, 2000) - otherwise when and how would the two axes separate? Which cells are the precursors of the rostral tip of the notochord and which cells contribute to the more caudal parts of this structure? If no head-tail axis exists at the beginning of the gastrula stage, then it must be generated later. Either cells for more caudal parts of the axis are born progressively (as in the leech and short-germ-band insects), or if there is no substantial "growth zone" (as in the fly), cells must first intercalate to elongate the primordium of the notochord and other axial structures and only then acquire positional identities along the axis as a result of cell interactions. On the other hand, there is indeed some evidence that Hoxgene boundaries are initially set up during gastrulation (before axial elongation), although both the organizer itself and the notochord derived from it do not express any Hoxgenes (Wacker et al., 2004a). The problem is made even more complex because the head-tail axis must be established for different structures (notochord, somites, intermediate and lateral meso- 
derm, the neural tube and the future gut tube) which develop at different times and in quite different ways, yet the resulting final pattern must be coherent so that organs are correctly aligned.

In the remainder of this review we will highlight the events that contribute to define the head-tail axis as we currently understand them and compare different Classes of vertebrates. We will follow a developmental chronology, from events occurring at early stages to later events.

\section{Earliest steps: breaking symmetry}

This is the process which we probably understand best and which has been studied very extensively in different vertebrates, but especially in amphibians. In Xenopus (reviewed by Gerhart, 2004), the animal-vegetal and the dorso-ventral axes are established first (during oogenesis and fertilization, respectively). These events rely on an interaction between the point of sperm entry and gravity (which positions the yolky cytoplasm vegetally). Immediately upon fertilization, the egg undergoes a cortical rotation which establishes the grey crescent at the dorsal side. Molecularly, the key components include VegT (a T-box transcription factor localized vegetally) and events that lead to later nuclear localization of $\beta$-catenin (representing activation of the Wnt pathway) at the dorsal side of the embryo. The region where the vegetal determinants and nuclear $\beta$-catenin overlap becomes the Nieuwkoop center, an important signaling region, defined by its expression of the transcription factor Siamois, which specifies the Spemann organizer in immediately neighboring cells towards the animal pole. In turn, the Spemann organizer emits signals (primarily BMP antagonists) which confer dorsal fates to cells within it and in adjacent regions. Downstream of these earliest molecular components, Nodal signaling (probably together with FGF) plays a critical role in mesoderm induction. The Spemann organizer corresponds to the dorsal lip of the blastopore - the position of the blastopore (but not most of its cells) marks the future caudal end (anus) of the tadpole. Thus, in Xenopus, maternal determinants along with gravity (cortical rotation) establish the first asymmetries which set up the animal-vegetal and dorso-ventral axes. The dorsal side corresponds to the site of initiation of the embryonic axis since this is where gastrulation begins. Subsequently the axis elongates by a combination of cell involution/ingression at the blastopore and strong convergence-extension movements, which affect both the animal ectoderm and the deep mesendodermal cells. These events cause the vegetal cells to be internalized and at the same time the blastopore/anus moves to where the vegetal pole used to be.

Zebrafish embryos appear to use similar mechanisms as Xenopus to break the initial symmetry of the egg and also establish a "dorsal" center (the shield) at one edge of the embryo through cooperation of similar pathways ( $\beta$-catenin/Wnt, a Siamoisrelated gene called bozozok/dharma/Nieuwkooid, a T-box gene called spadetail[ Tbx16] and the Nodal, BMP and FGF pathways) (reviewed in Kane and Warga, 2004; Solnica-Krezel, 2005). However because of the very large acellular yolk volume, the process of epiboly (spreading of the embryo over the yolk) is very prominent and coupled with gastrulation movements, which occur all around the disc-shaped embryo - not only around the shield on the dorsal side, but also at the opposite end. In addition gastrulation movements seem to continue over a much longer period than
Box 2. Ambiguities of terminology. In all vertebrates, but particularly in mouse and chick, much of the recent literature uses "anterior-posterior patterning" to describe events occurring at early stages of development. But the term amalgamates several different, and experimentally separable, events. One is the formation of the primitive streak at one end of the embryo (here we call this "symmetry breaking"). Another is the specification of the position ("anterior") in the blastoderm/blastocyst where the forebrain will later develop. The primitive streak appears at the opposite edge to the site of future forebrain development, where the tail will later form. However the cells that occupy these positions at early stages contribute very extensively to the axis. Furthermore the axis of the primitive streak itself is not a head-tail axis but rather a dorsalventral axis (the tip of the streak, where the node is located, contains dorsal cell fates like notochord but the descendants of these cells will extend along the whole axis; the "posterior" streak will give rise to lateral and extraembryonic mesoderm: ventral cell types; Psychoyos and Stern, 1996; Kinder et al., 1999; Tam and Gad, 2004). Therefore at the primitive streak stage, the axis bisecting the embryo into left and right halves runs from rostral at one end to ventral at the other (rather than rostral to caudal), and the cells that occupy these various positions do not relate to the future head-tail axis in any simple way. It is therefore misleading to think of the "anterior-posterior patterning" mechanisms that position the primitive streak as being equivalent to head-tail patterning, although obviously the early events are required for the correct execution of the later ones.

in Xenopus, cells are still involuting around the margin all around the embryo while neurulation is well underway in central embryonic regions. As a result, the process usually called "gastrulation" in zebrafish encompasses both this and most of the neurula stage in the frog.

In amniotes, we probably know most about these processes in the chick (reviewed in Stern, 2004). Although the chick egg possesses a very large acellular yolk volume like the zebrafish, gastrulation is not a protracted process because epiboly of the blastoderm over the yolk is uncoupled from gastrulation. Epiboly occurs at a later stage and its major purpose is to expand extraembryonic, rather than embryonic tissues. Unlike Xenopus, however, the egg is highly polyspermic and the embryo breaks its radial symmetry at a relatively late, highly multicellular stage. If maternal determinants exist (and there is evidence that gravity as the egg rotates in the mother's oviduct influences polarity and that " $\delta$-ooplasm" may be a critical maternal component; Kochav and Eyal-Giladi, 1971; Callebaut et al., 2001; Callebaut et al., 2004), they may establish a polarity bias but are not required for breaking symmetry. The clearest demonstration of this is the observation that when a "blastula" stage embryo (about 20,000 cells) is cut into several fragments, each fragment can spontaneously initiate formation of its own, complete, embryonic axis (Spratt and Haas, 1960; Bertocchini et al., 2004). The earliest known zygotic components that fix the polarity of the embryo involve a TGF $\beta(c V g \eta)$ and Wnt signals at the blastula stage, which activate Nodal in neighboring cells. Together with FGF, Nodal induces the formation of mesendoderm at the primitive streak (the equivalent of the amphibian blastopore and of the fish margin). As in the other organisms discussed, the position (but not the cells) of the primitive streak mark the future posterior pole of the embryo. Cells 
A

a
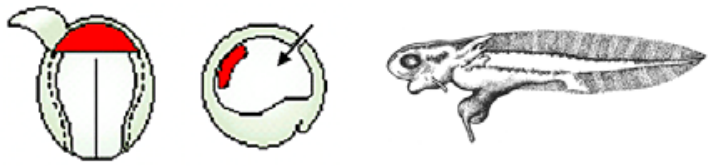

b
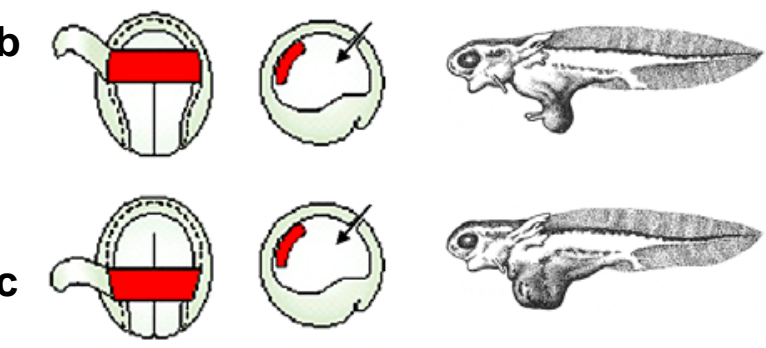

d
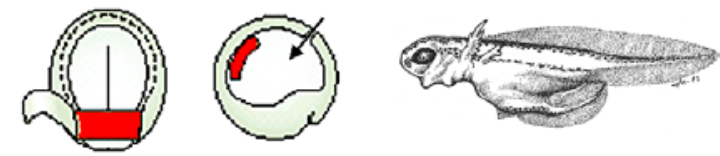

B
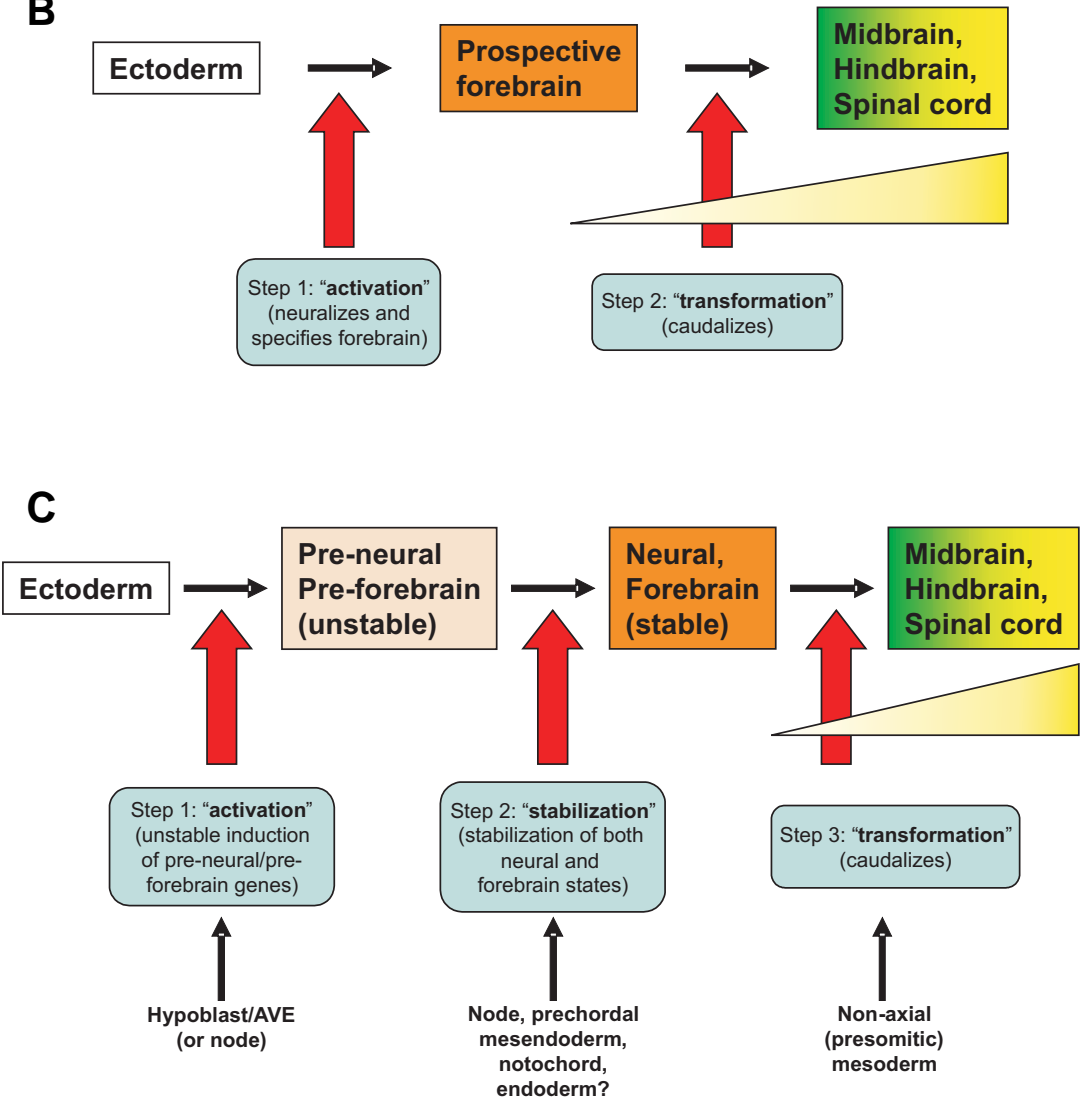

Fig. 2. Three models to explain initial head-tail patterning of the embryo. (A) The "head/trunk/tail organizer" model, based on the experiments of Otto Mangold (shown schematically in the first two columns, with the result on the right): grafts of "anterior" archenteron roof induce an ectopic head, those of mid-level roof induce trunk and those of caudalmost roof tissue induce a tail. (B) Nieuwkoop's "activation-transformation" model. (C) The "three-step" model, a modification of Nieuwkoop's model. giving rise to regions posterior to the hindbrain (in any germ layer) are located within a very small territory which only expands much later (Fraser and Stern, 2004; Stern, 2004). In amniotes (both chick and mouse) an additional mechanism prevents premature formation of the primitive streak as well as the formation of multiple streaks: an extraembryonic tissue (hypoblast in chick, anterior visceral endoderm or AVE in mouse) emits the Nodal antagonists Cerberus and Lefty. Primitive streak formation is delayed until these antagonists are cleared by movement of the hypoblast/AVE away from the site of streak initiation (Bertocchini and Stern, 2002; PereaGomez et al., 2002). This mechanism is probably required because of the relatively late stage at which polarity is established in amniotes, as a consequence of which any part of the embryo retains the ability to form a primitive streak until gastrulation starts (Spratt and Haas, 1960; Bertocchini et al., 2004).

In the mouse the earliest symmetry-breaking events establish an embryonic-abembryonic axis although the mechanisms of this and especially the extent to which maternal determinants play a role, are currently hotly debated (for example see Gardner and Davies, 2003; Hiiragi and Solter, 2004; Plusa et al., 2005). However it seems likely that the mechanisms that position the primitive streak are very similar to those described for chick (Tam and Gad, 2004). At the end of the "blastula" (blastocyst) stage, one end of what has become a hollow embryonic cylinder becomes the site of initiation of the primitive streak which, as in the other organisms discussed, corresponds to the position of the future anus; the head will develop at the opposite side of the cylinder. At the early primitive streak stage, the cells that will occupy all the different axial positions have not yet been set aside and it is therefore impossible to produce a fate map for the entire axis in the early embryo (Lawson et al., 1991; Tam and Gad, 2004). The mechanisms that set the position of the mouse primitive streak are largely unknown but they also involve Wnt and Nodal signaling (Morkel et al., 2003; Robertson et al., 2003; Tam and Gad, 2004). The extraembryonic endoderm (AVE) plays an important role in this early symmetry-breaking process not only by antagonizing primitive streak formation (PereaGomez et al., 2002) but also for induction and/or spatial restriction of a number of genes which are required at the opposite end of the embryo (Lu et al., 2001).

\section{Cell movements position the head territory}

Fate maps constructed at early gastrula stage (or 6 hours post-fertilization in the zebrafish; Woo and Fraser, 1995) show an orderly arrangement of the territories that will contribute to the future major brain regions (forebrain, midbrain, hindbrain), but these 
are not yet aligned along the future head-tail axis as defined by the position of the blastopore/shield/primitive streak. Extensive cell movements then distort the map and arrange most of the territories along this axis. This has been demonstrated most clearly in zebrafish and chick (Bortier and Vakaet, 1992; Hatada and Stern, 1994; Woo and Fraser, 1995; Fernandez-Garre et al., 2002; Fraser and Stern, 2004; Stern, 2004) (Fig. 1). Initially the forebrain is located medially and the hindbrain and spinal cord territories laterally in fate maps of both species. Cell movements then align them rostro-caudally from forebrain to hindbrain/spinal cord. In zebrafish this situation is attained at 10 hours post-fertilization, while in chick this is achieved at stage 4 (end of the gastrula stage). At this time, the fore- and midbrain regions are quite prominent in the fate map but the prospective hindbrain and spinal cord territories are comparatively very small. By contrast we know little about these events in either amphibians or mammals. Xenopus fate maps are very crude for these stages and often do not distinguish between territories destined for different regions of the nervous system (see Keller and Shook, 2004). In mouse, the only detailed fate maps available are those of Lawson and colleagues (Lawson et al., 1991) since other maps only start at a much later stage (Inoue et al., 2000). However the available data are consistent with findings in zebrafish and chick (Tam and Gad, 2004).

\section{Three models for the early stages}

Ever since the discovery of neural induction (Spemann and Mangold, 1924), embryologists have been intrigued by the mechanisms responsible for the activity of the organizer in both inducing the nervous system and patterning it appropriately (see Box 3; reviewed in Stern, 2001). An organizer graft results in an ectopic nervous system that contains all the appropriate subdivisions and the neighboring mesoderm becomes patterned to generate coherently aligned structures. An early model (Fig. 2) proposed to account for this followed Otto Mangold's observations (Mangold, 1933) that grafts of different levels of the archenteron roof (derived from both organizer and non-organizer blastoporal tissue and corresponding to mesoderm emerging at different times-see below) induce very specific regions of the nervous system. The most rostral tissue induces a head, intermediate levels induce a trunk and the most caudal levels induce a tail. Mangold proposed that there are several distinct organizers and that each region of the body is induced separately. This hypothesis is often called the "head/trunk/tail organizer model". In zebrafish and frog, misexpression of BMP antagonists such as Chordin or Noggin tend to generate ectopic head structures. This is even more efficient if the antagonists simultaneously inhibit both BMP and Wnt signals (Glinka et al., 1997). In contrast, misexpression of FGF can generate only trunk/tail structures even in the presence of BMP (Storey et al., 1998; Agathon et al., 2003; Kudoh et al., 2004). Findings such as these have broadly been interpreted as supporting the head/trunk/tail organizer model. In addition, the findings that the mouse AVE and chick anterior definitive endoderm are required for formation of the forebrain (Thomas and Beddington, 1996; Beddington and Robertson, 1998; Knoetgen et al., 1999; Withington et al., 2001) are considered to support the idea that in amniotes, a "head organizer" might reside in the hypoblast/AVE and/or the most rostral definitive endoderm (for discussion see Foley et al., 2000; Stern, 2001). However, al- though there is no question that these tissues are required for normal development of the axis, grafting experiments have demonstrated that neither the chick hypoblast nor the mouse AVE can induce neural fates and that neither can pattern neighboring tissues by itself (Tam and Steiner, 1999; Foley et al., 2000).

An alternative, the "activation-transformation model" (Fig. 2), was proposed by Nieuwkoop after observing that grafts of tissues into embryos gave rise to ectopic structures that were never more rostral than the level of the graft, but extended all the way to the tail (Nieuwkoop et al., 1952; Nieuwkoop and Nigtevecht, 1954). Nieuwkoop suggested that the initial induction ("activation") produced nervous system of rostral character and that later signals ("transformation") gradually modified parts of it to generate more caudal regions. Nieuwkoop proposed that the transforming signals are emitted by the organizer itself, but more recent evidence suggests that they may instead be produced by non-axial mesoderm (Muhr et al., 1997; Gould et al., 1998; Muhr et al., 1999; Wacker et al., 2004a). It is often assumed that BMP antagonists (which can induce head structures under certain circumstances) underlie the activation step, while three molecules have transforming (caudalizing) activity: Wnts (McGrew et al., 1997; Houart et al., 2002; Wilson and Houart, 2004), FGFs (Cox and HemmatiBrivanlou, 1995; Pownall et al., 1998) and Retinoic acid (Durston et al., 1989; Ruiz i Altaba and Jessell, 1991; Kessel, 1992; Avantaggiato et al., 1996; Blumberg et al., 1997; Grandel et al., 2002; Kudoh et al., 2002; Diez del Corral et al., 2003; Oosterveen et al., 2003; Sockanathan et al., 2003; Molotkova et al., 2005). However this model does not easily explain why older organizers can only induce caudal structures, without a head.

Recently a third alternative has been proposed, the "three-step model" (Stern, 2001; Fraser and Stern, 2004) (Fig. 2). This is a modification of Nieuwkoop's model but with an intermediate, "stabilization" step. It proposes that "activation" is not sufficient for induction of either neural or forebrain fates, but rather establishes an early but unstable ("pre-neural/pre-forebrain") state which requires consolidation by the next step. Later stabilizing signals, perhaps from the axial mesoderm or its precursors in the organizer, would consolidate neural fates (Muhr et al., 1997; Muhr et al., 1999; Wacker et al., 2004a). In the head region, stabilization (presumably from prechordal mesoderm; Foley et al., 1997; Pera and Kessel, 1997; Shimamura and Rubenstein, 1997) would fix both neural and forebrain states. In the trunk, stabilizing and transforming signals appear to emanate from different tissues:

Box 3. What is an "organizer"? An organizer is a group of cells that has the ability both to induce a new fate in neighboring cells and to pattern the induced tissues and/or other neighboring tissues. The Spemann organizer (the dorsal lip of the amphibian blastopore, the zebrafish shield, Hensen's node in birds and mammals) is the archetypal example: it is able to induce the formation of an ectopic nervous system from cells not fated to form a neural plate; the induced nervous system is appropriately patterned along its dorsoventral and head-tail axes and the organizer or its derivatives can also dorsalize the neighboring host mesoderm. Although there are many examples of inducing tissues and other cases when cells impart patterning information, there are probably very few (if any) other true organizers during development. 
while the organizer-derived axial mesoderm (notochord) is likely to be responsible for stabilization, the paraxial (non-organizer) mesoderm seems to be the source of transforming cues (Muhr et al., 1997; Gould et al., 1998; Muhr et al., 1999; Wacker et al., 2004a).

Further research is required, with experiments designed to test the specific predictions of these three, essentially incompatible, models.

\section{Post-gastrulation: specifying position in the meso- derm and non-head nervous system}

Whatever the mechanism, by the end of the gastrula stage, the vertebrate embryo has generated a relatively large territory containing precursors for the forebrain, midbrain and most rostral hindbrain and a much smaller territory containing cells that will contribute to the rest of the nervous system (from the middle of the hindbrain to the caudal end of the spinal cord) and mesoderm for the corresponding levels of the trunk and tail (Fig. 1). It seems remarkable that most of the body arises from such a small region and it therefore makes little sense to think of head-tail patterning as having already occurred largely before the end of the gastrula period.

After gastrulation, the embryo grows caudally, laying down structures as it does so. A characteristic body plan emerges when most of the trunk paraxial mesoderm has become segmented into somites, the body wall has folded to enclose the gut and a tail bud has formed (even if in some organisms this later regresses). This is the pharyngula (or phylotypic) stage, at which all vertebrates were once thought to resemble each other more than at any other stage of development (Haeckel, 1874; Richardson and Keuck, 2002). Somites arise from paraxial mesoderm emerging from the remnants of the blastopore/shield/primitive streak region, while the hindbrain/spinal cord are derived from small primordia located next to this. The remains of the organizer and adjacent cells define the "chordoneural hinge", a region that contains precursors for both the ventral midline of the nervous system from the hindbrain to the tail and for the notochord in the mesoderm (Selleck and Stern, 1991; Gont et al., 1993; Pfeffer and De Robertis, 1994; Catala et al., 1996). There is evidence in both chick (Selleck and Stern, 1991; Selleck and Stern, 1992; Freitas et al., 2001) and mouse (Beddington, 1994; Nicolas et al., 1996; Mathis and Nicolas, 2000; Cambray and Wilson, 2002) that Hensen's node contains a population of resident, asymmetrically dividing cells with stem-cell-like properties, which contribute to notochord and somites along the entire length of the axis from the hindbrain to the tail. As each of these cells divides, one daughter remains in the node and the other leaves to enter the prospective notochord or pre-somite mesoderm domains, where it continues to divide as it becomes situated progressively more rostrally with respect to an increasing number of more caudal neighbors (Fig. 3). This is reminiscent of the mechanisms that elongate the body plan of leeches and short germ band insects, discussed earlier. However, there is little information on this for Xenopus and it is possible that this animal, which develops very fast and without increasing its body volume, may rely more on cell intercalation to elongate the body axis from cells set aside during gastrulation, rather than adding a large number of new cells as the body grows post-gastrulation. If few or no new cells are generated in the tail,

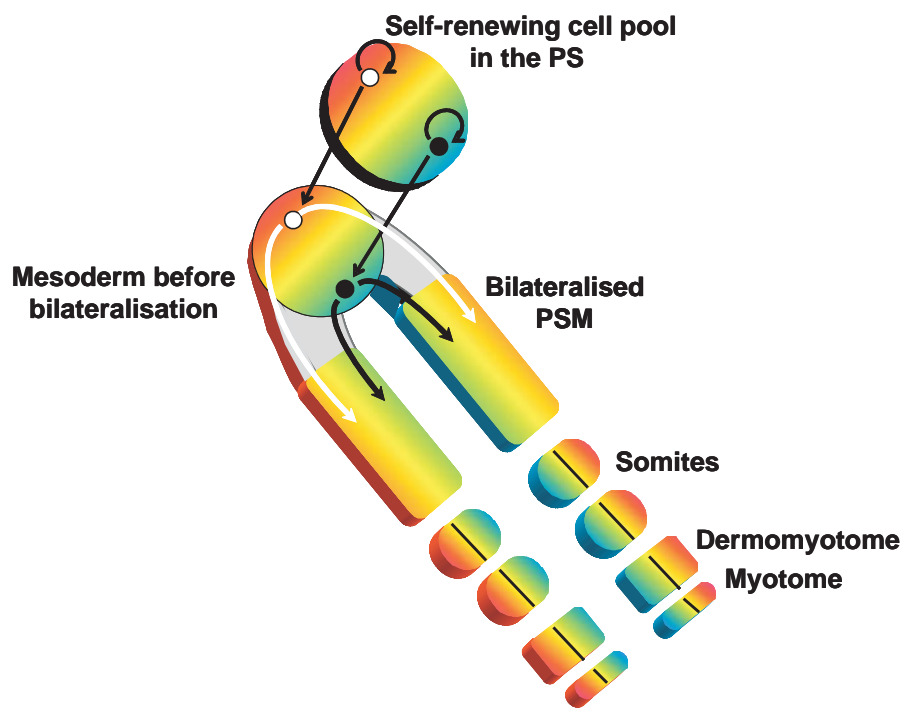

Fig. 3. Stem-cell-like cells resident in Hensen's node (circle on upper left of diagram) divide within the node. At each division, one daughter remains in the node while the other and its subseuqent progeny colonizes the paraxial (prospective somite) mesoderm (shown as bilateral rods extending towards the lower right of the diagram). From Eloy-Trinquet et al. (2002), in turn based on data from Selleck and Stern $(1991,1992)$ and Nicolas et al. (1996).

then it is conceivable that in anurans (perhaps even in all amphibians) most of the head-tail patterning occurs much earlier than in other vertebrates (more like Drosophila). On the other hand, if the intercalation movements are very extensive, early specification requires highly regulated cell movements to avoid cells losing their early-acquired identity, which seems very unlikely. In conclusion, it is most likely for all vertebrates that for the entire trunk, from hindbrain to tail, rostro-caudal identity is only finally fixed after the gastrula stage has finished (although gastrulation as a process continues in the tail bud and cells continue to acquire positional identities as the embryo elongates caudally).

\section{Hox genes and positional addresses}

From about the middle of the hindbrain to the tip of the tail, positional identity in both the nervous system and in mesodermal and endodermal organs is encoded by the combination of Hox genes expressed by the cells. In most vertebrates (except teleosts and some anurans, where clusters may be partially duplicated) the Hox genes are arranged in four linear clusters (a-d) each containing up to 13 genes (Fig. 4). Within each cluster, genes towards the 3' end are expressed earlier and extend more cranially than those more 5' (for reviews see McGinnis and Krumlauf, 1992; Kmita and Duboule, 2003). Similarly numbered (1-13) genes in different clusters (a-d) are called "paralogs" and tend to be expressed in a similar spatial domain. The basic structure of Hox clusters, as well as the spatial and temporal "colinearity" with the physical arrangement of genes along the chromosome, is conserved from Drosophila (which has only one cluster) to vertebrates (Fig. 4). Although Hox genes specify identity in different germ layers, their spatial and temporal expression is often not precisely aligned in the different layers: at least 
initially, expression usually extends further rostrally in the nervous system than in the adjacent mesoderm. Moreover the shift of expression domains between germ layers can differ in different species. There can be functional compensation between paralogous genes: while loss-of-function mutations in a single Hox gene in the mouse often have subtle if any consequences, inactivation of all four paralogs can cause a "homeotic" transformation, whereby the affected region (generally at the rostral end of the expression domains of the paralogs) will adopt the regional character of a different, generally more caudal, region (for example see (Horan et al., 1995). Indeed, the precise combination of Hox paralogs expressed in a particular region is thought to represent a "Hox code" (Kessel and Gruss, 1991) of positional identity. Thus, the "transformation" event in the Nieuwkoop model discussed above can interpreted molecularly as the sequential activation of more 5' Hox genes, specifying progressively more caudal positional identity. However, it is important to note that no Hox genes are expressed more rostrally than rhombomere 2 of the hindbrain and that an orderly arrangement of paralog expression domains is not found rostral to rhombomere 4.

Recent results suggest rather strongly that it is not so much the precise molecular identity of the genes expressed in a particular region that convey positional address, but rather the time of onset of their expression (transcriptional heterochrony; (Duboule, 1994; Crawford, 2003) that is critical. Thus, if Hoxd11 (which normally specifies L6 vertebral identity) is activated too early, the identity of the vertebrae expressing it shifts rostrally (to L5) whereas if it is activated too late it shifts caudally (to L7) (Gerard et al., 1997; Zakany et al., 1997). There is a strong link between the activation of genes along the cluster and proliferation and it has been proposed that cells may possess a counting mechanism for cell divisions that translates developmental history into positional identity along the axis (Gaunt and Strachan, 1994; Duboule, 1995). How do embryos coordinate the timing of Hox gene activation with the genesis of particular regions of the nervous system and mesoderm, to ensure that the structures arising from different germ layers are correctly aligned? One obvious possibility, based on the discovery of asymmetrically dividing, stem-celllike cells in Hensen's node and its remnants in the chordoneural hinge (see above and Fig. 3 ) is that the stem-cell-like progenitor remaining in the node continues to "open" the Hox clusters while its sister cell becomes committed as it emerges from the node region. A different timing mechanism, comprising spreading waves of expression of successive-Hox genes and their subsequent stabilization in the emerging mesoderm, has recently been demonstrated in Xenopus (Fig. 5): Hox gene expression is initiated very early, in a broad domain of the marginal zone (non-organizer mesoderm) at the gastrula stage. Each Hox paralog group is expressed there in a temporally colinear sequence so that this domain goes through a succession of transient Hox codes. At the dorsal boundary of this zone, Hox codes become stabilized by an organizer signal as the mesodermal cells leave this region and become laid down along the forming axis. At the end of each "flash" of marginal stabilization of a particular Hox code, the next Hox code is fixed and in turn resolves to the next cells entering the dorsal mesoderm, which is situated just caudal to the previous group of cells (Hooiveld et al., 1999; Wacker et al., 2004a). It will be very interesting to establish whether amniote embryos use a similar mechanism at an equivalent stage.
Clock-like mechanisms including waves of activation/repression of components of the Notch pathway (Palmeirim et al., 1997; Pourquie, 2004) and a cell cycle based timer (Stern et al., 1988; Primmett et al., 1989; Stern et al., 1992) have been proposed to regulate segmentation and this could easily account for the timer controlling Hox gene expression as cells leave the proliferating zone (Cordes et al., 2004). Despite the attractiveness of this hypothesis because of its simplicity, Hox gene expression can "spread" among adjacent cells as a result of cell interactions and is not fixed solely according to lineage history (Deschamps and Wijgerde, 1993; Gaunt and Strachan, 1994; Gaunt et al., 1999; Forlani et al., 2003). Moreover, cell interactions across germ layers are required at much later stages to fix the precise boundaries of Hox genes, which remain plastic for a long time. For example, signals from the paraxial mesoderm regulate the expression of Hoxb4 in the adjacent hindbrain long after both the hindbrain and the paraxial mesoderm have left the remnants of the primitive streak and node (Gould et al., 1998).

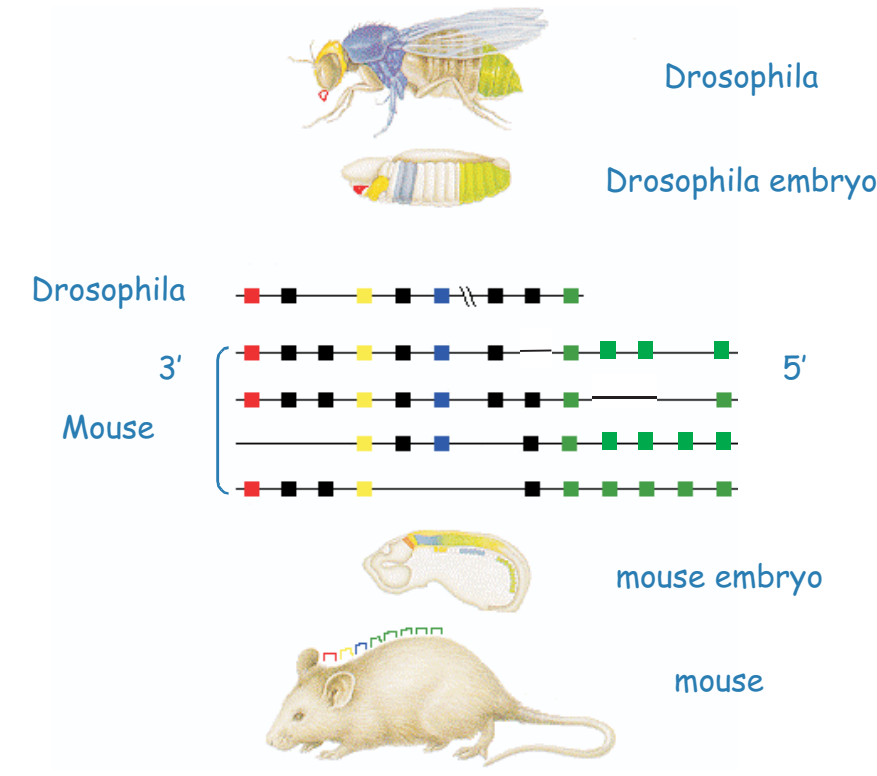

Fig. 4. Chromosomal organization of a Hox cluster and schematic expression pattern in Drosophila (upper) and mouse (lower). The fly has only one Hox cluster, while the mouse has four. Hox clusters are spatially and temporally colinear: genes situated towards the 3 ' end of the cluster (shown on the left in the diagrams) are expressed more rostrally and earlier than those closer to the $5^{\prime}$ end.

A very elegant mechanism to coordinate the segmentation clock with these later cell interactions involves a balance between FGF and retinoid signalling in the presomitic mesoderm (Dubrulle et al., 2001; Zakany et al., 2001; Diez del Corral et al., 2003; Sockanathan et al., 2003; Dubrulle and Pourquie, 2004; Moreno and Kintner, 2004; Shiotsugu et al., 2004). FGF8 is expressed as a gradient (strongest posteriorly) in the youngest part of the presomitic mesoderm and the most rostral boundary of the expression domain was proposed to correspond to a "maturation front", determining the commitment of cells to segment. On the other hand, retinoic acid opposes the FGF gradient and fixes its rostral boundary. At the same time, downregulation of FGF signaling at the rostral end of this domain in the presomitic 


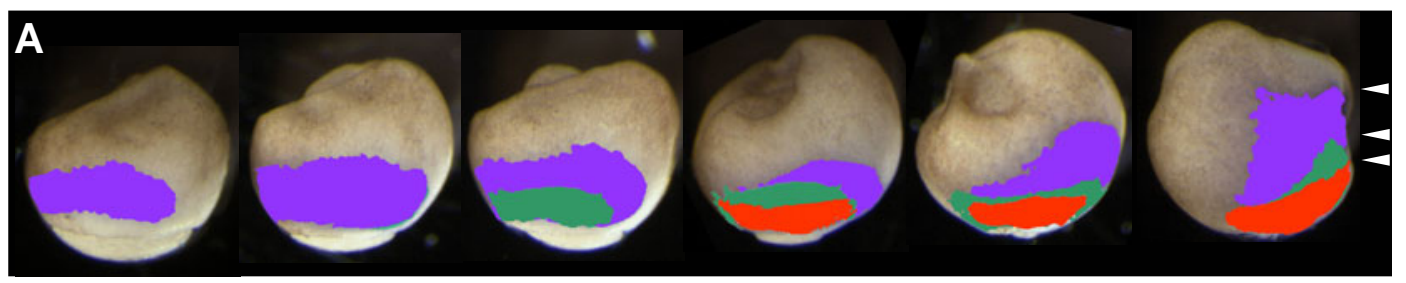

B
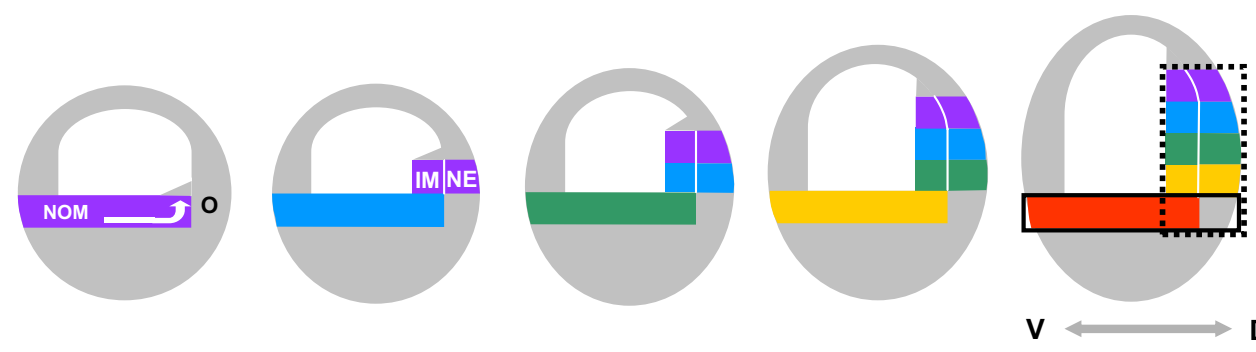

A

C

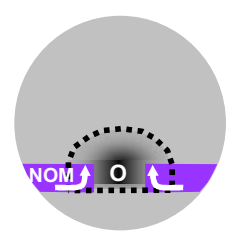

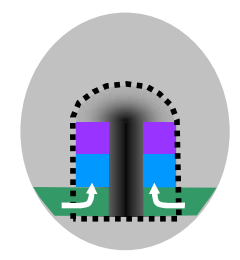
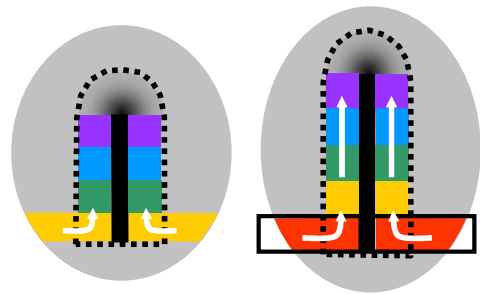

Chicken definitive streak

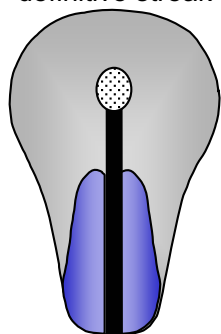

Hensen's node Primitive streak
L

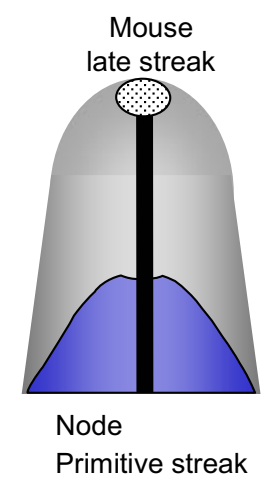

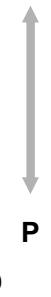

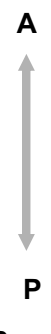

A
Spemann organizer Blastopore

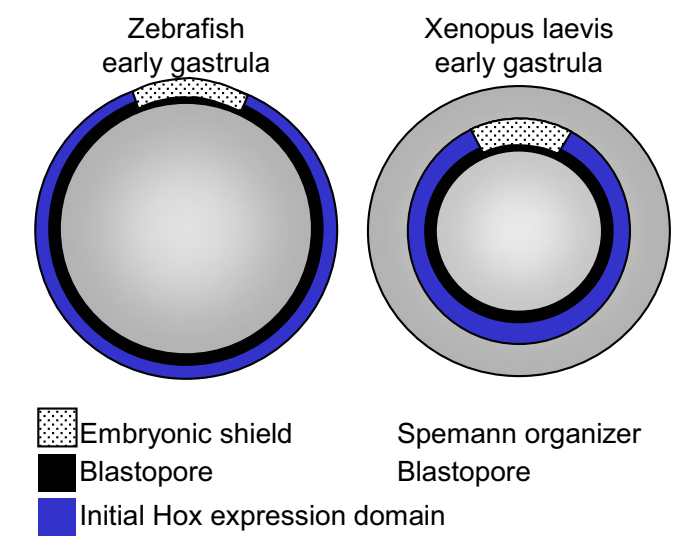
Blastopore Initial Hox expression domain

D

Fig. 5. The time-space translator model (from Wacker et al., 2004a). (A) False colour representation of expression of three Hox genes during Xenopus gastrulation: Hoxd-1 (purple), Hoxc-6 (green), Hoxb-9 (red). Six gastrula stages (10.5, 11, 11.5, 12, 12.5 and 13) are shown in a lateral view, anterior up and dorsal to the right. Anterior limits of Hox expression at the end of gastrulation are arrowed. (B) The time space translator model. Expression of new Hox genes (different colours) is initiated in non-organizer mesoderm (NOM) at different times. Non-organizer mesodermal tissue moves towards the Spemann organizer by convergence and then extends anteriorly (arrow). When mesoderm adjacent to the Spemann organizer involutes (IM), the current Hox code is transferred to overlying neurectoderm (NE). While the early Hox sequence in the non-organizer mesoderm (solid outlined black box) is running, new cells from this region are continuously moved into the range of the Spemann organizer (dashed black box) and their Hox code is then stabilized by an organizer signal. Thus, the temporal Hox sequence is converted into a spatial AP pattern by continuous morphogenetic movement and stabilization of timed information by the organizer in both involuted mesoderm (IM) and overlying neurectoderm (NE). (C) Dorsal views. In non-organizer mesodermal cells, the Hox sequence is running (solid black outline). From this domain, cells are continuously moved into the influence of the Spemann organizer (dashed black box) by convergence and extension (arrows). The head-tail pattern arises by adding new stabilized segments expressing a different subset of Hox genes caudally. A, anterior (rostral); $P$, posterior (caudal); $V$, ventral; $D$, dorsal; L, left; $R$ right. (D) Schematic diagrams depicting locations of the Spemann organizer, blastopore and initial Hox expression domain in Xenopus and orthologous structures in the zebrafish (Alexandre et al., 1996), chick (Gaunt and Strachan, 1996) and mouse (Deschamps et al., 1999) at the beginning of gastrulation. Zebrafish and Xenopus are shown in vegetal views, chick and mouse are shown in dorsal views (modified from Wacker et al., 2004a). 
mesoderm has been demonstrated to determine the timing of neuronal differentiation and PaxG expression in the adjacent spinal cord (Diez del Corral et al., 2002; Diez del Corral et al., 2003), providing a mechanism by which mesodermal segmentation and neuronal differentiation are coordinated in time and space. Importantly, Hox genes themselves appear to oscillate along with the segmentation clock during this process (Zakany et al., 2001). Although we don't yet understand the precise mechanism by which these events are coordinated, it seems likely that one role of FGF signaling in this process is to maintain plasticity in the cells receiving high levels of this signal, while loss of FGF signaling (perhaps as a result of retinoid signals) "fixes" the Hox code expressed at that time in the receiving cells in both germ layers. On the other hand, this conclusion makes it difficult to understand why opposing signals, retinoids and FGFs, both have caudalizing activity (see above). According to this model, one might expect FGF to act as caudalizing agent because it would keep cells in a "younger" state, allowing them to activate more 5' Hox genes. Exposure to retinoids causes caudal transformation (ie. a shift of caudal identity in a rostral direction) in both vertebrae and the nervous system (Simeone et al., 1990; Kessel and Gruss, 1991; Simeone et al., 1991; Marshall et al., 1992), yet the above model predicts the reverse. In addition to their activity in antagonizing FGF, retinoids also act directly to regulate Hox gene expression, as many of the Hox genes contain critical retinoidresponse elements within their regulatory regions (see Mavilio et al., 1988; Simeone et al., 1990; Gould et al., 1998; Huang et al., 1998; Packer et al., 1998; Liu et al., 2001; Bel-Vialar et al., 2002; Roelen et al., 2002; Mainguy et al., 2003; Oosterveen et al., 2003). Therefore the relationship between FGFs and retinoids in rostrocaudal patterning is not as simple as if it were controlled merely by two antagonistic gradients.

These mechanisms have been studied most intensively in the chick and mouse. As mentioned above, the process may be somewhat different in Xenopus. Since segmentation and caudal elongation of the spinal cord occur very rapidly and within a fixed volume of tissue, it is more difficult to envisage a protracted segmentation clock especially if this is linked to the cell cycle. Although there is some evidence for oscillations of Notch pathway components in this animal (Davis et al., 2001), these are not as clear as in amniotes and there are as yet few direct links between these and either segmentation, or neural differentiation, or the establishment of positional identity.

\section{The tail bud and completion of the gross pattern}

The caudal region is an area of continued growth and of cell recruitment even in Xenopus (Gont et al., 1993). In this region, some cells are still deciding between germ layers and even single cells can contribute progeny to more than one layer (Selleck and Stern, 1991; Catala et al., 1996; Brown and Storey, 2000). Cells at the midline may contribute to the floor plate of the neural tube and/or to the notochord. Although the most obvious evidence for regionalization along the axis can be found in the nervous system, paraxial mesoderm and endoderm and findings in amphibians suggest that the notochord may lack positional codes (Wacker et al., 2004a) there is some intriguing evidence suggesting that the notochord may also be segmentally organized and regionalized (Stern, 1990; Bundy et al., 1998; Prince et al., 1998; Kuan et al.,
2004). The floor plate, however, does not appear to be regionally subdivided: cells seem to be capable of migrating extensively along the head-tail axis (Stern et al., 1988). By contrast if the cells end up in even slighly more lateral regions of the neural tube they remain in place and acquire characteristic positional identity.

Continued elongation of the tail bud requires the action of the transcription factors Brachyury (Wacker et al., 2004b; Messenger et al., 2005) and Caudal (Pownall et al., 1996; Charite et al., 1998; Isaacs et al., 1998; Pownall et al., 1998; van den Akker et al., 2002; Chawengsaksophak et al., 2004; Copf et al., 2004; Beland and Lohnes, 2005). Misexpression of BrachyurymRNA in the frog induces only caudal structures whereas misexpression of a related T-box gene, VegT, induces head structures. Intriguingly this seems to be due to differential affinities of these transcription factors for the BMP effector Smad1: a C-terminal sequence in Brachyury is required for this interaction; if it is mutated, Brachyury can induce head structures (Messenger et al., 2005). This reveals the critical role of Brachyury in caudal extension, but it also provides another reminder of how difficult it is to disentangle the head-tail axis from dorsoventral patterning when misexpressing genes at early stages, since mutating the Smad1-interacting sequence in Brachyury also induces expression of the organizer (dorsal) marker goosecoid.

\section{Refining the pattern}

By the end of the processes discussed above, the embryo has generated a series of gross regions in each of the germ layers along the body axis. As each of these regions matures further, it becomes more complex and may become further subdivided. Thus the forebrain divides into telencephalic and diencephalic domains and then further into a series of smaller units (called prosomeres or prosencephalic neuromeres; (Vaage, 1969; Figdor and Stern, 1993; Puelles and Rubenstein, 1993; Puelles and Rubenstein, 2003), while the hindbrain becomes divided into 7 rhombomeres (Vaage, 1969; Lumsden and Keynes, 1989; Lumsden, 2004) each with characteristic identity and fate. A few additional regions with specific functions soon appear, including the boundary between midbrain and hindbrain (or isthmus; (Martinez and Alvarado-Mallart, 1990; Itasaki etal., 1991; Martinez et al., 1995) which has been particularly well studied. It is defined by its strong expression of $F G F \&$ and acts as a signaling region responsible for patterning both the adjacent midbrain (future tectum, where it generates graded expression of engrailed-2), as well as the first rhombomere, defining the future cerebellum (Wurst and Bally-Cuif, 2001). For these reasons the isthmus is usually considered as an "organizer". The isthmus is positioned as a result of juxtaposition of the expression domains of two antagonistic transcription factors, Otx2 rostrally and Gbx2 caudally, although we don't yet know the signals involved (Simeone, 2000). At these later stages, refinement of the pattern continues to be dependent on signals emanating from other germ layers for example signals from the paraxial mesoderm are critical in imparting positional identity to individual rhombomeres as well as to specific regions of the more caudal spinal cord (Ensini et al., 1998; Gould et al., 1998). Two important pathways have been identified as important in this process, which are reminiscent of those implicated in the putative "transforming" events in earlier development: retinoids (Gould et al., 1998) and the Wnt modula- 
tor Wise (Itasaki et al., 2003). However this makes it even more difficult to understand how such a small handful of signals can lead to the enormous diversity of regions and cell types along the body axis, both within the nervous system and in other layers. Is timing as important in this refining process as it is in earlier development? Are there other ways of generating such huge complexity using just two or three signals?

\section{Conclusions}

Over the last few decades, much has been learned about the mechanisms that establish head-tail pattern along the axis and gradually generate different regions along it, but there is a suprising number of major, outstanding questions. During early development, considerable information has been gathered about the initial events of head-tail patterning but there is even a lot of confusion about how the axes themselves are first defined and how much of the axis is specified at what time in development. To what extent can any of the three main models for initial head-tail patterning account for these events? Three pathways (FGFs, retinoids and Wnts) are used repeatedly in the process of headtail patterning, but how can they generate so many distinct regions, in three different germ layers? In the trunk, Hox gene colinearity specifies positional information; what transcription factors play the equivalent role in regions rostral to the hindbrain and how are their expression patterns regulated? Timing has turned out to be extremely important in patterning the body from hindbrain to tail, but the head appears to become subdivided by mechanisms that more closely resemble those that pattern long germ band insects (but this similarity is superficial and we have no idea of what these mechanisms might be). It is almost as if the head develops like a fly, while the trunk is like a leech or grasshopper. In anurans, timing appears to play a more minor role in this process than in "higher" vertebrates - could it be that the frog becomes regionalized more like a fly throughout its body? The Hoxclusters are not aligned in the same way in adjacent germ layers - what mechanisms coordinate these complex patterns and why are they different in different species? The answers to these major questions will no doubt include some very important and novel developmental principles.

\section{Summary}

When, where and how is the head-tail axis of the embryo set up during development? These are such fundamental and intensely studied questions that one might expect them to have been answered long ago. Not so; we still understand very little about the cellular or molecular mechanisms that lead to the orderly arrangement of body elements along the head-tail axis in vertebrates. In this paper, we outline some of the major outstanding problems and controversies and try to identify some reasons why it has been so difficult to resolve this important issue.

KEY WORDS: antero-posterior axis, AVE, hypoblast, hox gene, homeobox gene, Spemann Organizer

\section{Acknowledgements}

We are indebted to the European Union for funding this consortium as a Network of Excellence ("Cells into Organs") and to Andrea Streit for comments on the manuscript and help with producing Figure 1.

\section{References}

AGATHON, A., THISSE, C. and THISSE, B. (2003). The molecular nature of the zebrafish tail organizer. Nature 424: 448-452.

AKAM, M. (1987). The molecular basis for metameric pattern in the Drosophila embryo. Development 101: 1-22.

AVANTAGgIATO, V., ACAMPORA, D., TUORTO, F. AND SIMEONE, A. (1996). Retinoic acid induces stage-specific repatterning of the rostral central nervous system. Dev Biol175: 347-357.

BEDDINGTON, R. S. (1994). Induction of a second neural axis by the mouse node. Development 120: 613-620.

BEDDINGTON, R. S. AND ROBERTSON, E. J. (1998). Anterior patterning in mouse. Trends Genet 14: 277-284.

BEL-VIALAR, S., ITASAKI, N. AND KRUMLAUF, R. (2002). Initiating Hox gene expression: in the early chick neural tube differential sensitivity to FGF and RA signaling subdivides the HoxB genes in two distinct groups. Development 129: 5103-5115.

BELAND, M. AND LOHNES, D. (2005). Chicken ovalbumin upstream promotertranscription factor members repress retinoic acid-induced $\mathrm{Cdx} 1$ expression. $J$ Biol Chem 280: 13858-13862.

BERTOCCHINI, F., SKROMNE, I., WOLPERT, L. AND STERN, C. D. (2004). Determination of embryonic polarity in a regulative system: evidence for endogenous inhibitors acting sequentially during primitive streak formation in the chick embryo. Development 131: 3381-3390.

BERTOCCHINI, F. AND STERN, C. D. (2002). The hypoblast of the chick embryo positions the primitive streak by antagonizing nodal signaling. Dev Ce//3: 735744.

BLUMBERG, B., BOLAdO, J., JR., MORENO, T. A., KINTNER, C., EVANS, R. M. AND PAPALOPULU, N. (1997). An essential role for retinoid signaling in anteroposterior neural patterning. Development 124: 373-379.

BORTIER, H. AND VAKAET, L. C. (1992). Fate mapping the neural plate and the intraembryonic mesoblast in the upper layer of the chicken blastoderm with xenografting and time-lapse videography. Development Suppl: 93-97.

BROWN, J. M. AND STOREY, K. G. (2000). A region of the vertebrate neural plate in which neighbouring cells can adopt neural or epidermal fates. Curr Bio/10: 869-872.

BUNDY, J., ROGERS, R., HOFFMAN, S. AND CONWAY, S. J. (1998). Segmental expression of aggrecan in the non-segmented perinotochordal sheath underlies normal segmentation of the vertebral column. Mech Dev 79: 213-217.

CALLEBAUT, M., HARRISSON, F. AND BORTIER, H. (2001). Effect of gravity on the interaction between the avian germ and neighbouring ooplasm in inverted egg yolk balls. Eur J Morpho/39: 27-38.

CALLEBAUT, M., VAN NUETEN, E., HARRISSON, F. AND BORTIER, H. (2004). Induction and improved embryonic development by the nucleus of Pander in associated avian blastoderm parts: influence of delta or gamma ooplasm. $J$ Morpho/260: 201-208.

CAMBRAY, N. AND WILSON, V. (2002). Axial progenitors with extensive potency are localised to the mouse chordoneural hinge. Development 129: 4855-4866.

CATAlA, M., TEILlet, M. A., DE ROBERTIS, E. M. AND LE DOUARIN, M. L. (1996). A spinal cord fate map in the avian embryo: while regressing, Hensen's node lays down the notochord and floor plate thus joining the spinal cord lateral walls. Development 122: 2599-2610.

CHARITE, J., DE GRAAFF, W., CONSTEN, D., REIJNEN, M. J., KORVING, J. AND DESCHAMPS, J. (1998). Transducing positional information to the Hox genes: critical interaction of $\mathrm{cdx}$ gene products with position-sensitive regulatory elements. Development 125: 4349-4358.

CHAWENGSAKSOPHAK, K., DE GRAAFF, W., ROSSANT, J., DESCHAMPS, J. and BECK, F. (2004). Cdx2 is essential for axial elongation in mouse development. Proc Nat/ Acad Sci USA 101: 7641-7645.

CHIPMAN, A. D., ARTHUR, W. AND AKAM, M. (2004). A double segment periodicity underlies segment generation in centipede development. Curr Biol 14: 1250-1255.

COPF, T., SCHRODER, R. AND AVEROF, M. (2004). Ancestral role of caudal 
genes in axis elongation and segmentation. Proc Natl Acad Sci USA 101: 17711-17715.

CORDES, R., SCHUSTER-GOSSLER, K., SERTH, K. AND GOSSLER, A. (2004). Specification of vertebral identity is coupled to Notch signalling and the segmentation clock. Development 131: 1221-1233.

COWAN, C. R. AND HYMAN, A. A. (2004). Centrosomes direct cell polarity independently of microtubule assembly in C. elegans embryos. Nature 431: $92-$ 96.

COX, W. G. AND HEMMATI-BRIVANLOU, A. (1995). Caudalization of neural fate by tissue recombination and bFGF. Development 121: 4349-4358.

CRAWFORD, M. (2003). Hox genes as synchronized temporal regulators: implications for morphological innovation. J Exp Zoolog B Mol Dev Evol295: 1-11.

DAVIS, R. L., TURNER, D. L., EVANS, L. M. AND KIRSCHNER, M. W. (2001). Molecular targets of vertebrate segmentation: two mechanisms control segmental expression of Xenopus hairy2 during somite formation. Dev Ce//1: 553565.

DESCHAMPS, J. AND WIJGERDE, M. (1993). Two phases in the establishment of HOX expression domains. Dev Biol156: 473-480.

DIEZ DEL CORRAL, R., BREITKREUZ, D. N. AND STOREY, K. G. (2002). Onset of neuronal differentiation is regulated by paraxial mesoderm and requires attenuation of FGF signalling. Development 129: 1681-1691.

DIEZ DEL CORRAL, R., OLIVERA-MARTINEZ, I., GORIELY, A., GALE, E., MADEN, M. AND STOREY, K. (2003). Opposing FGF and retinoid pathways control ventral neural pattern, neuronal differentiation and segmentation during body axis extension. Neuron 40: 65-79.

DUBOULE, D. (1994). Temporal colinearity and the phylotypic progression: a basis for the stability of a vertebrate Bauplan and the evolution of morphologies through heterochrony. Development Suppl: 135-142.

DUBOULE, D. (1995). Vertebrate Hox genes and proliferation: an alternative pathway to homeosis? Curr Opin Genet Dev 5: 525-528.

DUBRULLE, J., MCGREW, M. J. AND POURQUIE, O. (2001). FGF signaling controls somite boundary position and regulates segmentation clock control of spatiotemporal Hox gene activation. Cel/106: 219-232.

DUBRULLE, J. AND POURQUIE, O. (2004). fgf8 mRNA decay establishes a gradient that couples axial elongation to patterning in the vertebrate embryo. Nature 427: 419-422.

DURSTON, A. J., TIMMERMANS, J. P., HAGE, W. J., HENDRIKS, H. F., DE VRIES, N. J., HEIDEVELD, M. AND NIEUWKOOP, P. D. (1989). Retinoic acid causes an anteroposterior transformation in the developing central nervous system. Nature 340: 140-144.

ENSINI, M., TSUCHIDA, T. N., BELTING, H. G. AND JESSELL, T. M. (1998). The control of rostrocaudal pattern in the developing spinal cord: specification of motor neuron subtype identity is initiated by signals from paraxial mesoderm. Development 125: 969-982.

FERNANDEZ-GARRE, P., RODRIGUEZ-GALLARDO, L., GALLEGO-DIAZ, V., ALVAREZ, I. S. AND PUELLES, L. (2002). Fate map of the chicken neural plate at stage 4. Development 129: 2807-2822.

FIGDOR, M. C. AND STERN, C. D. (1993). Segmental organization of embryonic diencephalon. Nature 363: 630-634.

FOLEY, A. C., SKROMNE, I. AND STERN, C. D. (2000). Reconciling different models of forebrain induction and patterning: a dual role for the hypoblast. Development 127: 3839-3854.

FOLEY, A. C., STOREY, K. G. AND STERN, C. D. (1997). The prechordal region lacks neural inducing ability, but can confer anterior character to more posterior neuroepithelium. Development 124: 2983-2996.

FORLANI, S., LAWSON, K. A. AND DESCHAMPS, J. (2003). Acquisition of Hox codes during gastrulation and axial elongation in the mouse embryo. Development 130: 3807-3819.

FRASER, S. E. AND STERN, C. D. (2004). Early rostrocaudal patterning of the mesoderm and neural plate, In Gastrulation: from cells to embryo, C. D. Stern, ed. (New York: Cold Spring Harbor Press), pp. 389-401.

FREITAS, C., RODRIGUES, S., CHARRIER, J. B., TEILLET, M. A. AND PALMEIRIM, I. (2001). Evidence for medial/lateral specification and positional information within the presomitic mesoderm. Development 128: 5139-5147.

GARDNER, R. L. AND DAVIES, T. J. (2003). The basis and significance of pre- patterning in mammals. Philos Trans R Soc Lond B Biol Sci358: 1331-1339.

GAUNT, S. J., DEAN, W., SANG, H. AND BURTON, R. D. (1999). Evidence that Hoxa expression domains are evolutionarily transposed in spinal ganglia and are established by forward spreading in paraxial mesoderm. Mech Dev82: 109118.

GAUNT, S. J. AND STRACHAN, L. (1994). Forward spreading in the establishment of a vertebrate Hox expression boundary: the expression domain separates into anterior and posterior zones and the spread occurs across implanted glass barriers. Dev Dyn 199: 229-240.

GERARD, M., ZAKANY, J. AND DUBOULE, D. (1997). Interspecies exchange of a Hoxd enhancer in vivo induces premature transcription and anterior shift of the sacrum. Dev Biol 190: 32-40.

GERHART, J. (2004). Symmetry breaking in the egg of Xenopus laevis, In Gastrulation: from cells to embryo, C. D. Stern, ed. (New York: Cold Spring Harbor Press), pp. 341-351.

GLINKA, A., WU, W., ONICHTCHOUK, D., BLUMENSTOCK, C. AND NIEHRS, C. (1997). Head induction by simultaneous repression of Bmp and Wnt signalling in Xenopus. Nature 389: 517-519.

GONT, L. K., STEINBEISSER, H., BLUMBERG, B. AND DE ROBERTIS, E. M. (1993). Tail formation as a continuation of gastrulation: the multiple cell populations of the Xenopus tailbud derive from the late blastopore lip. Development 119: 991-1004.

GOULD, A., ITASAKI, N. AND KRUMLAUF, R. (1998). Initiation of rhombomeric Hoxb4 expression requires induction by somites and a retinoid pathway. Neuron 21: 39-51.

GRANDEL, H., LUN, K., RAUCH, G. J., RHINN, M., PIOTROWSKI, T., HOUART, C., SORDINO, P., KUCHLER, A. M., SCHULTE-MERKER, S., GEISLER, R., et al. (2002). Retinoic acid signalling in the zebrafish embryo is necessary during pre-segmentation stages to pattern the anterior-posterior axis of the CNS and to induce a pectoral fin bud. Development 129: 2851-2865.

HAECKEL, E. (1874). Anthropogenie oder Entwickelungsgeschichte des Menschen. (Leipzig: Engelmann).

HIIRAGI, T. AND SOLTER, D. (2004). First cleavage plane of the mouse egg is not predetermined but defined by the topology of the two apposing pronuclei. Nature 430: 360-364.

HOOIVELD, M. H., MORGAN, R., IN DER RIEDEN, P., HOUTZAGER, E., PANNESE, M., DAMEN, K., BONCINELLI, E. AND DURSTON, A. J. (1999). Novel interactions between vertebrate Hox genes. Int J Dev Bio/43: 665-674.

HORAN, G. S., RAMIREZ-SOLIS, R., FEATHERSTONE, M. S., WOLGEMUTH, D. J., BRADLEY, A. AND BEHRINGER, R. R. (1995). Compound mutants for the paralogous hoxa-4, hoxb-4 and hoxd-4 genes show more complete homeotic transformations and a dose-dependent increase in the number of vertebrae transformed. Genes Dev 9: 1667-1677.

houART, C., CANEPARO, L., hEISENBERG, C., BARTH, K., TAKE-UCHI, M. AND WILSON, S. (2002). Establishment of the telencephalon during gastrulation by local antagonism of Wnt signaling. Neuron 35: 255-265.

HUANG, D., CHEN, S. W., LANGSTON, A. W. AND GUDAS, L. J. (1998). A conserved retinoic acid responsive element in the murine Hoxb-1 gene is required for expression in the developing gut. Development 125: 3235-3246.

HUYNH, J. R. AND ST JOHNSTON, D. (2004). The origin of asymmetry: early polarisation of the Drosophila germline cyst and oocyte. Curr Bio/14: R438-449.

INOUE, T., NAKAMURA, S. AND OSUMI, N. (2000). Fate mapping of the mouse prosencephalic neural plate. Dev Bio/219: 373-383.

ISAACS, H. V., POWNALL, M. E. AND SLACK, J. M. (1998). Regulation of Hox gene expression and posterior development by the Xenopus caudal homologue Xcad3. EMBO J17: 3413-3427.

ITASAKI: N., ICHIJO, H., HAMA, C., MATSUNO, T. AND NAKAMURA, H. (1991). Establishment of rostrocaudal polarity in tectal primordium: engrailed expression and subsequent tectal polarity. Development 113: 1133-1144.

ITASAKI, N., JONES, C. M., MERCURIO, S., ROWE, A., DOMINGOS, P. M., SMITH, J. C. AND KRUMLAUF, R. (2003). Wise, a context-dependent activator and inhibitor of Wnt signalling. Development 130: 4295-4305.

KANE, D. A. AND WARGA, R. M. (2004). Teleost gastrulation, In Gastrulation: from cells to embryo, C. D. Stern, ed. (New York: Cold Spring Harbor Press), pp. 157169. 
KELLER, R. AND SHOOK, D. (2004). Gastrulation in amphibians, In Gastrulation: from cells to embryo, C. D. Stern, ed. (New York: Cold Spring Harbor Press), pp. 171-204.

KESSEL, M. (1992). Respecification of vertebral identities by retinoic acid. Deve/opment 115: 487-501.

KESSEL, M. AND GRUSS, P. (1991). Homeotic transformations of murine vertebrae and concomitant alteration of Hox codes induced by retinoic acid. Ce//67: 89-104.

KINDER, S. J., TSANG, T. E., QUINLAN, G. A., HADJANTONAKIS, A. K., NAGY, A. AND TAM, P. P. (1999). The orderly allocation of mesodermal cells to the extraembryonic structures and the anteroposterior axis during gastrulation of the mouse embryo. Development 126: 4691-4701.

KMITA, M. AND DUBOULE, D. (2003). Organizing axes in time and space; 25 years of colinear tinkering. Science 301: 331-333.

KNOETGEN, H., VIEBAHN, C. AND KESSEL, M. (1999). Head induction in the chick by primitive endoderm of mammalian, but not avian origin. Development 126: 815-825.

KOCHAV, S. AND EYAL-GILADI, H. (1971). Bilateral symmetry in chick embryo determination by gravity. Science 171: 1027-1029

KUAN, C. Y., TANNAHILL, D., COOK, G. M. AND KEYNES, R. J. (2004). Somite polarity and segmental patterning of the peripheral nervous system. Mech Dev 121: 1055-1068.

KUDOH, T., CONCHA, M. L., HOUART, C., DAWID, I. B. AND WILSON, S. W. (2004). Combinatorial Fgf and Bmp signalling patterns the gastrula ectoderm into prospective neural and epidermal domains. Development131: 3581-3592.

KUDOH, T., WILSON, S. W. AND DAWID, I. B. (2002). Distinct roles for Fgf, Wnt and retinoic acid in posteriorizing the neural ectoderm. Development 129: 43354346.

LALL, S. AND PATEL, N. H. (2001). Conservation and divergence in molecular mechanisms of axis formation. Annu Rev Genet 35: 407-437.

LANE, M. C. AND SHEETS, M. D. (2000). Designation of the anterior/posterior axis in pregastrula Xenopus laevis. Dev Bio/225: 37-58.

LAWSON, K. A., MENESES, J. J. AND PEDERSEN, R. A. (1991). Clonal analysis of epiblast fate during germ layer formation in the mouse embryo. Development 113: 891-911.

LIU, J. P., LAUFER, E. AND JESSELL, T. M. (2001). Assigning the positional identity of spinal motor neurons: rostrocaudal patterning of Hox-c expression by FGFs, Gdf11 and retinoids. Neuron 32: 997-1012.

LU, C. C., BRENNAN, J. AND ROBERTSON, E. J. (2001). From fertilization to gastrulation: axis formation in the mouse embryo. Curr Opin Genet Dev 11: 384 392.

LUMSDEN, A. (2004). Segmentation and compartition in the early avian hindbrain. Mech Dev 121: 1081-1088.

LUMSDEN, A. AND KEYNES, R. (1989). Segmental patterns of neuronal development in the chick hindbrain. Nature 337: 424-428.

MAINGUY, G., IN DER RIEDEN, P. M., BEREZIKOV, E., WOLTERING, J. M. PLASTERK, R. H. AND DURSTON, A. J. (2003). A position-dependent organisation of retinoid response elements is conserved in the vertebrate $\mathrm{Hox}$ clusters. Trends Genet 19: 476-479.

MANGOLD, O. (1933). Über die Induktionsfähighkeit der verschiedenen Bezirke der Neurula von Urodelen. Naturwissenshaften 21: 761-766.

MARSHALL, H., NONCHEV, S., SHAM, M. H., MUCHAMORE, I., LUMSDEN, A. AND KRUMLAUF, R. (1992). Retinoic acid alters hindbrain Hox code and induces transformation of rhombomeres $2 / 3$ into a 4/5 identity. Nature $360: 737$ 741.

MARTINEZ, S. AND ALVARADO-MALLART, R. M. (1990). Expression of the homeobox Chick-en gene in chick/quail chimeras with inverted mes-metencephalic grafts. Dev Bio/139: 432-436.

MARTINEZ, S., MARIN, F., NIETO, M. A. AND PUELLES, L. (1995). Induction of ectopic engrailed expression and fate change in avian rhombomeres: intersegmental boundaries as barriers. Mech Dev 51: 289-303.

MATHIS, L. AND NICOLAS, J. F. (2000). Different clonal dispersion in the rostral and caudal mouse central nervous system. Development 127: 1277-1290.

MAVILIO, F., SIMEONE, A., BONCINELLI, E. AND ANDREWS, P. W. (1988). Activation of four homeobox gene clusters in human embryonal carcinoma cells induced to differentiate by retinoic acid. Differentiation 37: 73-79.

MCGINNIS, W. AND KRUMLAUF, R. (1992). Homeobox genes and axial patterning. Cel/68: 283-302

MCGREW, L. L., HOPPLER, S. AND MOON, R. T. (1997). Wnt and FGF pathways cooperatively pattern anteroposterior neural ectoderm in Xenopus. Mech Dev 69: 105-114.

MESSENGER, N. J., KABITSCHKE, C. ANDREWS, R., GRIMMER, D., MIGUEL, R. N., BLUNDELL, T. L., SMITH, J. C. AND WARDLE, F. C. (2005). Functiona specificity of the Xenopus T-domain protein brachyury is conferred by its ability to interact with smad1. Dev Ce//8: 599-610.

MOLOTKOVA, N., MOLOTKOV, A., SIRBU, I. O. AND DUESTER, G. (2005). Requirement of mesodermal retinoic acid generated by Raldh2 for posterio neural transformation. Mech Dev122: 145-155.

MORENO, T. A. AND KINTNER, C. (2004). Regulation of segmental patterning by retinoic acid signaling during Xenopus somitogenesis. Dev Ce//6: 205-218.

MORKEL, M., HUELSKEN, J., WAKAMIYA, M., DING, J., VAN DE WETERING, M., CLEVERS, H., TAKETO, M. M., BEHRINGER, R. R., SHEN, M. M. AND BIRCHMEIER, W. (2003). Beta-catenin regulates Cripto- and Wnt3-dependent gene expression programs in mouse axis and mesoderm formation. Development 130: 6283-6294

MUHR, J., GRAZIANO, E., WILSON, S., JESSELL, T. M. AND EDLUND, T. (1999). Convergent inductive signals specify midbrain, hindbrain and spinal cord identity in gastrula stage chick embryos. Neuron 23: 689-702.

MUHR, J., JESSELL, T. M. AND EDLUND, T. (1997). Assignment of early caudal identity to neural plate cells by a signal from caudal paraxial mesoderm. Neuron 19: 487-502.

NICOLAS, J. F., MATHIS, L., BONNEROT, C. AND SAURIN, W. (1996). Evidence in the mouse for self-renewing stem cells in the formation of a segmented longitudinal structure, the myotome. Development 122: 2933-2946.

NIEUWKOOP, P. D., BOTTERNENBROOD, E. C., KREMER, A., BLOESMA, F. F. S. N., HOESSELS, E. L. M. J., MEYER, G. AND VERHEYEN, F. J. (1952) Activation and organization of the Central Nervous System in Amphibians. JExp Zool120: 1-108.

NIEUWKOOP, P. D. AND NIGTEVECHT, G. V. (1954). Neural activation and transformation in explants of competent ectoderm under the influence of fragments of anterior notochord in urodeles. JEmbryo/ ExpMorpho/2: 175-193.

OOSTERVEEN, T., NIEDERREITHER, K., DOLLE, P., CHAMBON, P., MEIJLINK, F. AND DESCHAMPS, J. (2003). Retinoids regulate the anterior expression boundaries of $5^{\prime}$ Hoxb genes in posterior hindbrain. EMBO J22: 262-269.

PACKER, A. I., CROTTY, D. A., ELWELL, V. A. AND WOLGEMUTH, D. J. (1998). Expression of the murine Hoxa4 gene requires both autoregulation and a conserved retinoic acid response element. Development 125: 1991-1998.

PALMEIRIM, I., HENRIQUE, D., ISH-HOROWICZ, D. AND POURQUIE, O. (1997). Avian hairy gene expression identifies a molecular clock linked to vertebrate segmentation and somitogenesis. Cel/91: 639-648.

PERA, E. M. AND KESSEL, M. (1997). Patterning of the chick forebrain anlage by the prechordal plate. Development 124: 4153-4162.

PEREA-GOMEZ, A., VELLA, F. D., SHAWLOT, W., OULAD-ABDELGHANI, M., CHAZAUD, C., MENO, C., PFISTER, V., CHEN, L., ROBERTSON, E., HAMADA $\mathrm{H}$., et al. (2002). Nodal antagonists in the anterior visceral endoderm prevent the formation of multiple primitive streaks. Dev Ce//3: 745-756.

PFEFFER, P. L. AND DE ROBERTIS, E. M. (1994). Regional specificity of RAR gamma isoforms in Xenopus development. Mech Dev 45: 147-153.

PLUSA, B., HADJANTONAKIS, A. K., GRAY, D., PIOTROWSKA-NITSCHE, K. JEDRUSIK, A., PAPAIOANNOU, V. E., GLOVER, D. M. AND ZERNICKAGOETZ, M. (2005). The first cleavage of the mouse zygote predicts the blastocyst axis. Nature 434: 391-395.

POURQUIE, O. (2004). The chick embryo: a leading model in somitogenesis studies. Mech Dev 121: 1069-1079.

POWNALL, M. E., ISAACS, H. V. AND SLACK, J. M. (1998). Two phases of Hox gene regulation during early Xenopus development. Curr Bio/8: 673-676.

POWNALL, M. E., TUCKER, A. S., SLACK, J. M. AND ISAACS, H. V. (1996). eFGF, Xcad3 and Hox genes form a molecular pathway that establishes the anteroposterior axis in Xenopus. Development 122: 3881-3892.

PRIMMETT, D. R., NORRIS, W. E., CARLSON, G. J., KEYNES, R. J. AND STERN, 
C. D. (1989). Periodic segmental anomalies induced by heat shock in the chick embryo are associated with the cell cycle. Development 105: 119-130.

PRINCE, V. E., PRICE, A. L. AND HO, R. K. (1998). Hox gene expression reveals regionalization along the anteroposterior axis of the zebrafish notochord. Dev Genes Evo/208: 517-522.

PSYCHOYOS, D. AND STERN, C. D. (1996). Fates and migratory routes of primitive streak cells in the chick embryo. Development 122: 1523-1534.

PUELLES, L. AND RUBENSTEIN, J. L. (1993). Expression patterns of homeobox and other putative regulatory genes in the embryonic mouse forebrain suggest a neuromeric organization. Trends Neurosci 16: 472-479.

PUELLES, L. AND RUBENSTEIN, J. L. (2003). Forebrain gene expression domains and the evolving prosomeric model. Trends Neurosci26: 469-476.

RICHARDSON, M. K. AND KEUCK, G. (2002). Haeckel's ABC of evolution and development. Biol Rev Camb Philos Soc 77: 495-528.

ROBERTSON, E. J., NORRIS, D. P., BRENNAN, J. AND BIKOFF, E. K. (2003). Control of early anterior-posterior patterning in the mouse embryo by TGF-beta signalling. Philos Trans R Soc Lond B Biol Sci358: 1351-1357.

ROELEN, B. A., DE GRAAFF, W., FORLANI, S. AND DESCHAMPS, J. (2002). Hox cluster polarity in early transcriptional availability: a high order regulatory level of clustered Hox genes in the mouse. Mech Dev 119: 81-90.

RUIZ I ALTABA, A. AND JESSELL, T. M. (1991). Retinoic acid modifies the pattern of cell differentiation in the central nervous system of neurula stage Xenopus embryos. Development 112: 945-958.

SELLECK, M. A. AND STERN, C. D. (1991). Fate mapping and cell lineage analysis of Hensen's node in the chick embryo. Development 112: 615-626.

SELLECK, M. A. J. AND STERN, C. D. (1992). Evidence for stem cells in the mesoderm of Hensen's node and their role in embryonic pattern formation., In Formation and differentiation of early embryonic mesoderm., R. Bellairs, E. J. Sanders and J. W. Lash, eds. (New York: Plenum Press), pp. 23-31.

SHIMAMURA, K. AND RUBENSTEIN, J. L. (1997). Inductive interactions direct early regionalization of the mouse forebrain. Development 124: 2709-2718.

SHIOTSUGU, J., KATSUYAMA, Y., ARIMA, K., BAXTER, A., KOIDE, T., SONG, J., CHANDRARATNA, R. A. AND BLUMBERG, B. (2004). Multiple points of interaction between retinoic acid and FGF signaling during embryonic axis formation. Development 131: 2653-2667.

SIMEONE, A. (2000). Positioning the isthmic organizer where Otx2 and Gbx2meet. Trends Genet 16: 237-240.

SIMEONE, A., ACAMPORA, D., ARCIONI, L. ANDREWS, P. W., BONCINELLI, E. AND MAVILIO, F. (1990). Sequential activation of HOX2 homeobox genes by retinoic acid in human embryonal carcinoma cells. Nature 346: 763-766.

SIMEONE, A., ACAMPORA, D., NIGRO, V., FAIELLA, A., D'ESPOSITO, M., STORNAIUOLO, A., MAVILIO, F. AND BONCINELLI, E. (1991). Differential regulation by retinoic acid of the homeobox genes of the four HOX loci in human embryonal carcinoma cells. Mech Dev 33: 215-227.

SOCKANATHAN, S., PERLMANN, T. AND JESSELL, T. M. (2003). Retinoid receptor signaling in postmitotic motor neurons regulates rostrocaudal positional identity and axonal projection pattern. Neuron 40: 97-111.

SOLNICA-KREZEL, L. (2005). Conserved Patterns of Cell Movements during Vertebrate Gastrulation. Curr Bio/15: R213-R228.

SPEMANN, H. AND MANGOLD, H. (1924). Induction of embryonic primordia by implantation of organizers from a different species. Roux' Arch EntwMech Org 100: 599-638. Re-edition of Viktor Hamburger's translation of the original 1924 paper entitled Über Induktion von Embryonalanlagen durch Implantation artfremder Organisatoren Int. J. Dev. Biol. 45: 13-38 (2001)

SPRATT, N. T. AND HAAS, H. (1960). Integrative mechanisms in development of the early chick blastoderm. I. Regulative potentiality of separated parts. J Exp Zoo/145: 97-137.

STERN, C. D. (1990). Two distinct mechanisms for segmentation? Semin Dev Biol 1: $109-116$
STERN, C. D. (2001). Initial patterning of the central nervous system: how many organizers? Nat Rev Neurosci2: 92-98.

STERN, C. D. (2004). Gastrulation in the chick, In Gastrulation: from cells to embryo, C. D. Stern, ed. (New York: Cold Spring Harbor Press), pp. 219-232.

STERN, C. D., FRASER, S. E., KEYNES, R. J. AND PRIMMETT, D. R. (1988). A cell lineage analysis of segmentation in the chick embryo. Development 104 Suppl: 231-244.

STERN, C. D., hATAdA, Y., SELlECK, M. A. AND STOREY, K. G. (1992). Relationships between mesoderm induction and the embryonic axes in chick and frog embryos. Development Suppl: 151-156.

STOREY, K. G., GORIELY, A., SARGENT, C. M., BROWN, J. M., BURNS, H. D., ABUD, H. M. AND HEATH, J. K. (1998). Early posterior neural tissue is induced by FGF in the chick embryo. Development 125: 473-484.

TAM, P. P. AND STEINER, K. A. (1999). Anterior patterning by synergistic activity of the early gastrula organizer and the anterior germ layer tissues of the mouse embryo. Development 126: 5171-5179.

TAM, P. P. L. AND GAD, J. L. (2004). Gastrulation in the mouse embryo, In Gastrulation: from cells to embryo, C. D. Stern, ed. (New York: Cold Spring Harbor Press), pp. 233-262.

TAUTZ, D. (2004). Segmentation. Dev Cel/7: 301-312.

THOMAS, P. AND BEDDINGTON, R. (1996). Anterior primitive endoderm may be responsible for patterning the anterior neural plate in the mouse embryo. Curr Bio/6: 1487-1496.

VAAGE, S. (1969). The segmentation of the primitive neural tube in chick embryos (Gallus domesticus). A morphological, histochemical and autoradiographical investigation. Ergeb Anat Entwicklungsgesch 41: 3-87.

VAN DEN AKKER, E., FORLANI, S., CHAWENGSAKSOPHAK, K., DE GRAAFF, W., BECK, F., MEYER, B. I. AND DESCHAMPS, J. (2002). Cdx1 and Cdx2 have overlapping functions in anteroposterior patterning and posterior axis elongation. Development 129: 2181-2193.

WACKER, S. A., JANSEN, H. J., MCNULTY, C. L., HOUTZAGER, E. AND DURSTON, A. J. (2004a). Timed interactions between the Hox expressing nonorganiser mesoderm and the Spemann organiser generate positional information during vertebrate gastrulation. Dev Bio/268: 207-219.

WACKER, S. A., MCNULTY, C. L. AND DURSTON, A. J. (2004b). The initiation of Hox gene expression in Xenopus laevis is controlled by Brachyury and BMP-4. Dev Bio/266: 123-137.

WILSON, S. W. AND HOUART, C. (2004). Early steps in the development of the forebrain. Dev Cel/6: 167-181.

WITHINGTON, S., BEDDINGTON, R. AND COOKE, J. (2001). Foregut endoderm is required at head process stages for anteriormost neural patterning in chick. Development 128: 309-320.

WOO, K. AND FRASER, S. E. (1995). Order and coherence in the fate map of the zebrafish nervous system. Development 121: 2595-2609.

WURST, W. AND BALLY-CUIF, L. (2001). Neural plate patterning: upstream and downstream of the isthmic organizer. Nat Rev Neurosci2: 99-108.

ZAKANY, J., GERARD, M., FAVIER, B. AND DUBOULE, D. (1997). Deletion of a HoxD enhancer induces transcriptional heterochrony leading to transposition of the sacrum. EMBO J16: 4393-4402.

ZAKANY, J., KMITA, M., ALARCON, P., DE LA POMPA, J. L. AND DUBOULE, D. (2001). Localized and transient transcription of Hox genes suggests a link between patterning and the segmentation clock. Ce//106: 207-217.

Received: September 2005

Reviewed by Referees: September 2005

Modified by Authors and Accepted for Publication: October 2005 